\title{
Isolation of the Thrombospondin Membrane Receptor
}

\author{
Adam S. Asch, John Barnwell," Roy L. Silverstein, and Ralph L. Nachman \\ Division of Hematology-Oncology and the Specialized Center of Research in Thrombosis, Cornell University Medical College; and the \\ *Department of Molecular Parasitology, New York University Medical Center, New York 10021
}

\begin{abstract}
Thrombospondin (TSP), a 450-kD multifunctional glycoprotein with a broad tissue distribution, is secreted upon platelet stimulation, binds to the activated platelet surface, and supports platelet aggregation. We have identified and isolated an 88-kD membrane glycoprotein present in platelets, endothelial cells, monocytes, and a variety of human tumor cell lines that is the membrane binding site for TSP. Endogenous platelet TSP binding to thrombin- and ionophore-stimulated human platelets was inhibited in the presence of the monoclonal antibody OKM5. TSP binding to C32 melanoma cells and HT1080 fibrosarcoma cells was specific and also inhibitable with OKM5 Mab. Cell labeling followed by specific immunoprecipitation demonstrated biosynthesis of a single 88-kD glycoprotein. Binding of TSP to the isolated membrane protein was specific and saturable. These studies identify an $\mathbf{8 8 - k D}$ membrane glycoprotein that reacts with the monoclonal antibody, OKM5, and may function as the cellular TSP receptor.
\end{abstract}

\section{Introduction}

Adhesive macromolecules play a central role in biology. By mediating cell-cell and cell-substrate interactions, they provide a framework upon which cell migration and morphogenesis occur during development $(1,2)$. Adhesive phenomena are also necessary for normal hemostasis in the adult organism (3) and play a role in the metastatic behavior of certain tumors (4-13). Although some adhesive molecules are intrinsic to the cell membrane, most are ligands for cellular receptors (14-19).

Platelet aggregation is a useful paradigm for characterizing cell adhesion phenomena. In vivo endothelial cell damage or denudation results in platelet adhesion with subsequent degranulation and the recruitment of additional platelets to form a plug. Platelet alpha granules contain numerous adhesive proteins, including von Willebrand factor, fibronectin, fibrinogen, and thrombospondin (TSP), ${ }^{1}$ that are secreted upon platelet stimulation, bind to the platelet membrane, and mediate aggregation (20-26). Fibrinogen links aggregating platelets by binding to the glycoprotein IIb/IIIa complex (GPIIb/IIIa) on opposing membranes (27). Von Willebrand factor and fibronectin share the

Address correspondence to Adam S. Asch, M.D., Division of Hematology-Oncology, Cornell University Medical College, 1300 York Ave., New York, NY 10021.

Received for publication 17 July 1986.

1. Abbreviations used in this paper: GP, glycoprotein; Mab, monoclonal antibody; MEM, minimum essential medium; TSP, thrombospondin.

J. Clin. Invest.

(C) The American Society for Clinical Investigation, Inc. 0021-9738/87/04/1054/08 \$1.00

Volume 79, April 1987, 1054-1061 capacity to bind to GPIIb/IIIa and have in common a four amino acid cellular binding domain, Arg-Gly-Asp-Ser (28-36). The GPIIb/IIIa complex has recently been identified in a variety of cells other than platelets, including endothelial cells (37), smooth muscle cells, and fibroblasts (38). Thus, this receptor complex and family of adhesive proteins are likely to have broad biological importance. Thrombospondin, a major alpha granule glycoprotein (39-43), differs from this family of proteins in that binding to the platelet surface does not appear to be mediated by GPIIb/ IIIa. Binding of TSP occurs normally on platelets from patients with Glanzmann's thrombasthenia-an inherited deficiency of platelet GPIIb/IIIa $(44,45)$. Thus, a separate receptor for TSP must exist.

TSP is an adhesive $450-\mathrm{kD}$ multifunctional glycoprotein composed of three identical disulfide-linked chains (46-48). TSP has a broad tissue distribution and is synthesized by endothelial cells $(49,50)$, fibroblasts (51), smooth muscle cells (52), alveolar pneumocytes (53), monocytes (54), and neuroglial cells (55) and is incorporated into the matrix of growing cells $(51,56)$. TSP is known to bind heparin $(39,41)$, fibrinogen $(57)$, fibronectin $(58$, 59 ), histidine-rich glycoprotein (60), collagen (61), and plasminogen (62). It has lectinlike properties (63) and is necessary for irreversible platelet aggregation (64). TSP has also recently been reported to mediate the adherence to endothelium of red cells parasitized with Plasmodium falciparum (65).

A monoclonal antibody (Mab), OKM5 (Ortho Diagnostic Systems Inc., Raritan, NJ), is reactive with platelets, endothelial cells, and monocytes $(66,67)$. It identifies an $88-\mathrm{kD}$ glycoprotein, and has recently been found to inhibit the cytoadherence of parasitized red cells to endothelial cell monolayers and the human melanoma cell line C32 (68). These observations raise the possibility that the antigen identified by OKM5 Mab is the cellular TSP receptor.

We report the isolation of an 88-kD membrane glycoprotein reactive with OKM5 Mab that binds TSP and may function as the cellular receptor for TSP.

\section{Methods}

Materials. OKM5 monoclonal antibody was kindly provided by Dr. G. Goldstein (Ortho Diagnostics Systems Inc.). A10, a monoclonal antibody with reactivity against decay accelerating factor (69) was a gift from Dr. T. Kinoshita (New York University Medical Center). C6.7 a monoclonal antibody that inhibits platelet aggregation (70) was a gift from Dr. V. Dixit. Monoclonal anti-TSP antibodies 11.4 and 45.2 were prepared and characterized as reported (71). Thrombin was a gift from Dr. J. Fenton. A23187 was purchased from Calbiochem-Behring Corp., La Jolla, CA. ${ }^{125}$ Iodine, ${ }^{3} \mathrm{H}$-mannose, ${ }^{3} \mathrm{H}$-fucose, ${ }^{3} \mathrm{H}$-galactosamine, and ${ }^{3} \mathrm{H}$-glucosamine were purchased from Amersham Corp., Arlington Heights, IL. TSP was prepared from human platelets and iodinated as previously described (60). Monospecific immunoaffinity-purified Fab antibody to TSP was prepared and iodinated as previously described (62). Rabbit polyclonal anti-GPIV IgG was a gift from Dr. G. Jamieson and Dr. N. Tandon (National Red Cross, Bethesda, MD). Monospecific rabbit polyclonal anti-GPV antisera (72) was a gift of Dr. K. J. Clemetson 
(Theodore Kocher Institute, Bern, Switzerland). The tetrapeptide ArgGly-Asp-Ser was purchased from Peninsula Laboratories, Belmont, CA.

Cells. C32 melanoma cells and HT1080 fibrosarcoma cells were obtained from American Type Culture Collection, Rockville, MD, and were maintained in culture in Eagle's minimum essential medium (MEM) and $10 \%$ fetal calf serum (FCS).

Cell binding studies. The expression of TSP on the surface of stimulated human platelets was measured with ${ }^{125} \mathrm{I}$-anti TSP Fab. Plateletrich plasma $(0.5 \mathrm{ml})$ was incubated with ${ }^{125} \mathrm{I}$-anti TSP Fab $4,000 \mathrm{cpm} /$ $\mu \mathrm{g}$ and $10 \mu \mathrm{g} / \mathrm{ml} \mathrm{OKM5} \mathrm{Mab}$ or a control anti-platelet monoclonal. Ionophore A23187 $(10 \mu \mathrm{g} / \mathrm{ml})$ was added for 2 min without stirring and the platelets were centrifuged for $8 \mathrm{~min}$ through silicone oil as previously described (64). Bound radioactivity was quantified with an Isodyne gamma counter (Searle, Amsterdam, Netherlands), and inducible TSP expression was calculated as the difference between counts obtained with resting and stimulated platelets. Thrombin-inducible TSP expression was measured similarly with gel-filtered human platelets. Thrombin (final concentration, $1 \mathrm{U} / \mathrm{ml}$ ) was added to platelets incubated with ${ }^{125} \mathrm{I}$-anti TSP Fab in the presence or absence of OKM5 Mab (final concentration, $10 \mu \mathrm{g} / \mathrm{ml}$ ) without stirring for $1 \mathrm{~min}$. Platelet pellets were obtained and counted as described above, and the difference between resting and stimulated bound radioactivity expressed as thrombin-inducible TSP.

The effect of OKM5 Mab (final concentration, $10 \mu \mathrm{g} / \mathrm{ml}$ ) on ${ }^{125} \mathrm{I}$ TSP binding to HT1080 cells was examined in suspension cultures. HT1080 cells grown in MEM with 10\% FCS were centrifuged and resuspended in serum-free MEM at a concentration of $10^{6} \mathrm{cells} / \mathrm{ml}$. Triplicate $0.1-\mathrm{ml}$ aliquots were incubated at $4^{\circ} \mathrm{C}$ with ${ }^{125} \mathrm{I}-\mathrm{TSP}(16,000 \mathrm{cpm} /$ pmol) over a range of concentrations. At $2 \mathrm{~h}$, the cells were centrifuged through silicone oil as described previously, and bound radioactivity was counted. The effect of polyclonal rabbit anti-glycoprotein (GP) IV antibody on TSP binding was also examined at the $100 \mu \mathrm{g} / \mathrm{ml}$ TSP point. Data were subjected to analysis with a modification of the Ligand program $(73,74)$.

The effect of OKM5 Mab (final concentration, $10 \mu \mathrm{g} / \mathrm{ml}$ ) on ${ }^{125} \mathrm{I}$ TSP binding to $\mathrm{C} 32$ melanoma cells was examined over a range of TSP concentrations at $4^{\circ} \mathrm{C}$ for $2 \mathrm{~h}$. Cells grown in culture flasks were resuspended in Hepes buffer containing $0.02 \%$ EDTA and then resuspended in MEM for the binding studies that were performed in triplicate. At 2 $h$, the cells were centrifuged through silicone oil and the radioactivity of the pellets was counted. The time course of binding was examined similarly at $4^{\circ} \mathrm{C}$ at $200 \mu \mathrm{g} / \mathrm{ml}$ TSP. Binding to monolayers grown in 24-well culture plates was performed similarly in MEM over a range of TSP concentrations at $4^{\circ} \mathrm{C}$. At $2 \mathrm{~h}$ incubation, the wells were gently washed thrice with MEM and the cells were solubilized with $1 \%$ Triton X-100 in phosphate buffered saline (PBS), pH 7.4.

Isolation of the membrane binding site. Isolation of the $88-\mathrm{kD}$ glycoprotein receptor from C32 melanoma cells and from human platelets was achieved with immunoaffinity column chromatography using an OKM5 Mab-Affigel 10 column. Cells were solubilized in PBS, pH 7.4, with $1 \%$ Triton $\mathrm{X}-100$ in the presence of protease inhibitors. Following extensive washing, bound antigen was eluted from the column with 0.2 $\mathrm{M}$ glycine, $\mathrm{pH} 2.5$, dialyzed against PBS, $\mathrm{pH} 7.4$, and electrophoresed in a 7.5\% sodium dodecyl sulfate-polyacrylamide (SDS-PAGE) gel (75). The material was electrophoretically transferred to nitrocellulose paper and incubated with purified TSP $(50 \mu \mathrm{g} / \mathrm{ml})$ in PBS, $\mathrm{pH} 7.4$, with $0.05 \%$ Tween, $2 \mathrm{mM} \mathrm{CaCl}_{2}, 2 \mathrm{mM} \mathrm{MgCl}_{2}$, and $1 \%$ bovine serum albumin. Following washing in several changes of buffer, the nitrocellulose was probed with colloidal gold-labeled goat anti-rabbit antibody and developed with Auroprobe (Janssen Life Sciences Products, Piscataway, NJ). Western blotting of the immunoisolated material was performed by incubating with rabbit anti-GPIV IgG $(50 \mu \mathrm{g} / \mathrm{ml})$, monospecific anti-GPV antisera (1:50 dilution), or normal rabbit antisera. Following extensive washing, detection was completed with peroxidase-conjugated goat antirabbit IgG and the colorimetric substrate 4-chloro-1-napthol. Two-dimensional gel electrophoresis of the immunoisolated material was performed using a modification of the O'Farrel method as previously described (55).

Biosynthetic labeling of the membrane binding site. $\mathrm{C} 32$ cell cultures grown in MEM with $10 \% \mathrm{FCS}$ were labeled with ${ }^{3} \mathrm{H}$-mannose, ${ }^{3} \mathrm{H}$-fucose, ${ }^{3} \mathrm{H}$-galactosamine, or ${ }^{3} \mathrm{H}$-glucosamine for $24 \mathrm{~h}(0.5 \mathrm{mCi} / \mathrm{ml})$ and solubilized in PBS, pH 7.4, with 1\% Triton X. OKM5 Mab bound to Affigel 10 beads was used to immunoprecipitate antigen. Following extensive washing, the beads were boiled in $0.12 \mathrm{M}$ Tris, $\mathrm{pH} 6.8,2 \% \mathrm{SDS}, 5 \%$ glycerol, $2.5 \%$ dithiothreitol, electrophoresed in a $7.5 \%$ SDS-PAGE gel, and autoradiography was performed.

TSP binding to the purified membrane binding site. The specificity of binding of TSP to the membrane protein was examined using purified material in enzyme-linked immunosorbent assay studies. TSP or albumin $(4 \mu \mathrm{g} / \mathrm{ml})$ were bound to the bottom of microtitre wells as previously described $(62,76)$. Purified OKM5 antigen $(4 \mu \mathrm{g} / \mathrm{ml})$ in PBS, Tween $0.05 \%$, pH 7.4, was incubated in the wells for $90 \mathrm{~min}$ at $37^{\circ} \mathrm{C}$. Wells were washed three times in buffer, and OKM5 Mab $(2 \mu \mathrm{g} / \mathrm{ml})$ was added to detect bound receptor. After additional washes, goat anti-mouse antibody conjugated to alkaline phosphatase was added and the bound OKM5 was quantified by the addition of the colorimetric substrate $p$ nitrophenyl phosphate.

The affinity of TSP for the isolated membrane protein was examined in binding studies using OKM5 antigen immobilized in microtitre wells. Immobilized OKM5 antigen was incubated with TSP or albumin in concentrations up to $400 \mu \mathrm{g} / \mathrm{ml}$, and binding was quantified using alkaline phosphatase conjugated second antibody and colorimetric substrate. Binding was examined in the presence of anti-TSP monoclonals C6.7 $(500 \mu \mathrm{g} / \mathrm{ml}), 11.4(100 \mu \mathrm{g} / \mathrm{ml})$, or $45.2(100 \mu \mathrm{g} / \mathrm{ml})$. Binding was also examined in the presence of the tetrapeptide Arg-Gly-Asp-Ser $(0.12 \mathrm{mM}$ and $1.2 \mathrm{mM}$ ) or $5 \mathrm{mM}$ ethylene diamino tetra acetic acid. In an additional test of specificity, preincubation of the immobilized membrane binding site with OKM $5 \mathrm{Mab}(10 \mu \mathrm{g} / \mathrm{ml})$ was done in control experiments before the addition of TSP.

\section{Results}

OKM5 Mab inhibits endogenous TSP binding to the platelet surface. Upon platelet stimulation, TSP is released from alpha granules and binds to the platelet surface (77). Recent studies have demonstrated TSP binding to resting as well as stimulated platelets (44). To examine the expression on the platelet surface of endogenous platelet TSP, we measured the binding of ${ }^{125} \mathrm{I}$ labeled affinity-purified monospecific rabbit anti-TSP Fab to thrombin- and ionophore-stimulated platelets. Gel-filtered human platelets were stimulated with $1 \mathrm{U} / \mathrm{ml}$ thrombin for $2 \mathrm{~min}$ in the presence of ${ }^{125} \mathrm{I}$-anti TSP Fab and with either OKM5 Mab $(10 \mu \mathrm{g} / \mathrm{ml})$ or a control anti-platelet Mab (Fig. 1). Thrombin-inducible TSP expression was completely inhibited in the presence of OKM5 Mab. The control anti-platelet Mab had no effect on TSP expression. Inhibition of TSP expression was not due to inhibition of release or aggregation, because in the presence of OKM5, thrombin aggregation was normal by aggregometry. In addition, platelet stimulation with the ionophore A23187 yielded similar results (Fig. 1). Ionophore-induced TSP expression was abrogated in the presence of OKM5 Mab.

OKM5 Mab inhibits TSP binding to human tumor cell lines. Using human fibrosarcoma HT1080 cells in suspension, binding of ${ }^{125} \mathrm{I}$-TSP was studied over a range of concentrations, in the presence of $10 \mu \mathrm{g} / \mathrm{ml} \mathrm{OKM} 5 \mathrm{Mab}$ or irrelevent Mab. Data were subjected to analysis by the computerized Ligand program adapted for use with an IBM PC (EBDA and SCAFIT programs) and revealed an apparent dissociation constant of 200-500 nM and 80,000 sites per cell. HT 1080 binding of ${ }^{125}$ I-TSP was dramatically inhibited by $10 \mu \mathrm{g} / \mathrm{ml}$ OKM5 Mab, but not control Mab. Binding was also inhibited by $50 \mu \mathrm{g} / \mathrm{ml}$ polyclonal rabbit anti-GPIV antibody (Fig. 2).

The human melanoma cell line, C32, has been used for studies on the cytoadherence of Plasmodium falciparum par- 


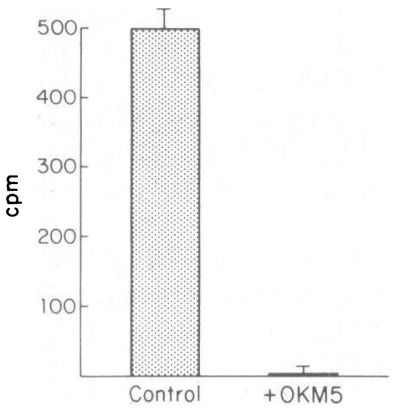

A

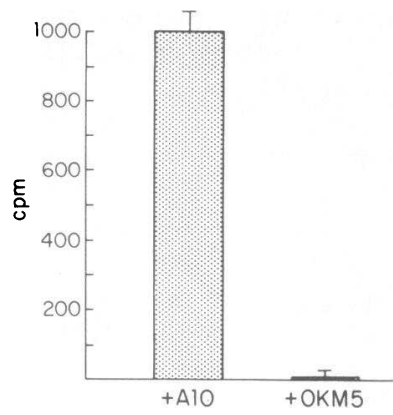

B

Figure 1. Inducible platelet TSP expression. Thrombin- and A23187inducible TSP expression on the platelet surface as measured by ${ }^{125} \mathrm{I}-$ anti TSP Fab was studied. $(A)$, Gel-filtered human platelets were activated with $1 \mathrm{U} / \mathrm{ml}$ thrombin in the presence of ${ }^{125} \mathrm{I}$-anti TSP Fab. The platelets were pelleted through silicone oil and bound radioactivity was counted. Thrombin-inducible TSP expression in the presence of $10 \mu \mathrm{g} / \mathrm{ml}$ OKM5 Mab was completely inhibited. (B), results of similar experiments using the calcium ionophore $\mathrm{A} 23187$ as the platelet agonist. Platelet-rich plasma was incubated with $10 \mu \mathrm{M}$ A23187 for 2 min in the presence of ${ }^{125} \mathrm{I}$-anti TSP Fab. Inducible TSP expression was completely inhibited by OKM $5 \mathrm{Mab}(10 \mu \mathrm{g} / \mathrm{ml})$. A control anti-platelet monoclonal (A10) that reacts with decay accelerating factor (69) did not have any effect on TSP expression. Bars indicate \pm SD.

asitized erythrocytes because of the relative ease of culture compared with human endothelial cells (78). OKM5 Mab reacts with $\mathrm{C} 32$ cells and has recently been reported to inhibit the cytoadherence of parasitized erythrocytes (68). We examined the binding of TSP to C32 cell suspensions and monolayers using ${ }^{125} \mathrm{I}-\mathrm{TSP}$ in the presence of $10 \mu \mathrm{g} / \mathrm{ml}$ of OKM5 Mab or a control Mab. At saturation, TSP binding was inhibited by 10 $\mu \mathrm{g} / \mathrm{ml}$ OKM5 (Fig. 3). Similar results were obtained with C32 cell monolayers. The time course of binding was examined at $4^{\circ} \mathrm{C}$ and a TSP concentration of $200 \mu \mathrm{g} / \mathrm{ml}$ (Fig. 4). Binding was rapid with half maximal binding by $10 \mathrm{~min}$ and maximal binding at $90 \mathrm{~min}$.

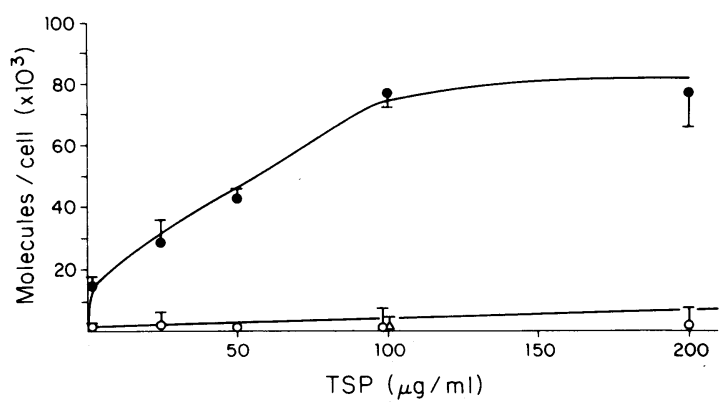

Figure 2. ${ }^{125} \mathrm{I}$-TSP binding to HT 1080 cells. HT 1080 cells grown in suspension cultures were washed free of serum-containing medium and resuspended at a concentration of $10^{6}$ cells $/ \mathrm{ml} .{ }^{125} \mathrm{I}$-TSP was added at several concentrations, and incubation was carried out at $4^{\circ} \mathrm{C}$ for $2 \mathrm{~h}$. Cells were pelleted through silicone oil and bound radioactivity was counted. Nonspecific binding as determined by the $\mathrm{Li}$ gand program $(73,74)$ was subtracted from total binding to determine specific binding. In the presence of $10 \mu \mathrm{g} / \mathrm{ml}$ OKM5 Mab (open circles) specific ${ }^{125}$ I-TSP binding was inhibited when compared with the binding in the presence of an irrelevent monoclonal (solid circles). Similar inhibition of TSP binding was observed with specific polyclonal anti-GPIV antibody (triangle). Error bars indicate \pm SD.

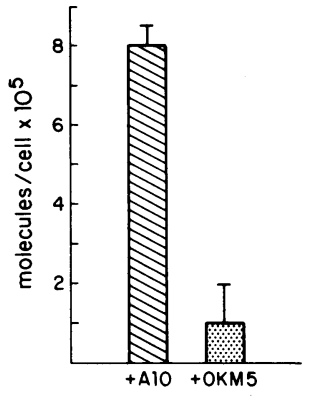

Figure 3. ${ }^{125} \mathrm{I}$-TSP binding to $\mathrm{C} 32$ melanoma cells. $\mathrm{C} 32$ cells grown in tissue culture flasks and resuspended were incubated with ${ }^{125} \mathrm{I}$-TSP. Following incubation with TSP at $4^{\circ} \mathrm{C}$ for $2 \mathrm{~h}$ the cells were centrifuged through silicone oil and bound radioactivity was counted. Bar graph depicts binding at saturation $(100$ $\mu \mathrm{g} / \mathrm{ml}$ ). In the presence of OKM5 Mab, ${ }^{125}$ I-TSP binding was dramatically inhibited. Error bars denote SD.

Isolation of the membrane TSP binding site. Using an OKM5 Mab affinity column, the binding site was isolated from C32 melanoma cells and platelets and electrophoresed in a 7.5\% SDSPAGE gel. The silver-stained gel is shown in Fig. 5. Lane 1 is the protein immunoisolated from human platelets; lane 2 is derived from C32 melanoma cells. A single major band that migrates with an apparent molecular weight of $88 \mathrm{kD}$ is present in both lanes. In two dimensional O'Farrel gels, the $88-\mathrm{kD}$ material had an isoelectric point (pI) of 4.5-5.5 (not shown), consistent with previously published data on GPIV (79).

Biosynthetic labeling of the binding site. To demonstrate endogenous synthesis of the OKM5 antigen, immunoprecipitation with OKM5 Mab-sepharose was used to purify an $88-\mathrm{kD}$ glycoprotein from ${ }^{3} \mathrm{H}$-mannose, -fucose, -glucosamine, or -galactosamine-labeled C32 cells. Fig. 6 is an autoradiogram prepared from a 7.5\% SDS-PAGE gel revealing a single band of $88 \mathrm{kD}$ in lanes 1-4 (lane 1, mannose; lane 2, fucose; lane 3, glucosamine; lane 4, galactosamine). Lane 5 is a control lane of material immunoprecipitated by normal mouse IgG, no radioactive material is present.

TSP binding to the purified membrane protein. The immunoisolated binding site was subjected to 7.5\% SDS-PAGE, electrophoretically transferred to nitrocellulose paper and incubated with TSP $(50 \mu \mathrm{g} / \mathrm{ml})$ probed with affinity-purified monospecific anti-TSP Fab and visualized with a gold-labeled second antibody and the Auroprobe detection system (Janssen, Life Sciences Products). In Fig. 7, lane 1, an $88-\mathrm{kD}$ platelet-derived species demonstrates TSP binding confirming the molecular weight of the TSP binding material. Similar findings were obtained with material immunoisolated from $\mathrm{C} 32$ cells. The binding was specific, because control lanes with albumin or column flowthrough did not bind TSP. In addition, Western blotting of the immunoisolated material using a specific polyclonal anti-GPIV an-

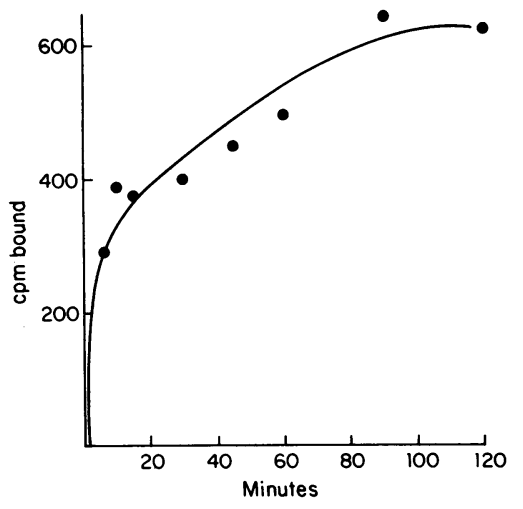

Figure 4. Time course of binding of ${ }^{125} \mathrm{I}$-TSP to C32 melanoma cell monolayers. $\mathrm{C} 32$ cells grown in tissue culture flasks and then resuspended were incubated with ${ }^{125} \mathrm{I}$-TSP $(200 \mu \mathrm{g} /$ $\mathrm{ml})$ at $4^{\circ} \mathrm{C}$. At various time points, the cells were pelleted through silicone oil, and the bound counts were quantified. Binding was rapid, with maximal

binding by $90 \mathrm{~min}$ and half-maximal binding by $10 \mathrm{~min}$. 


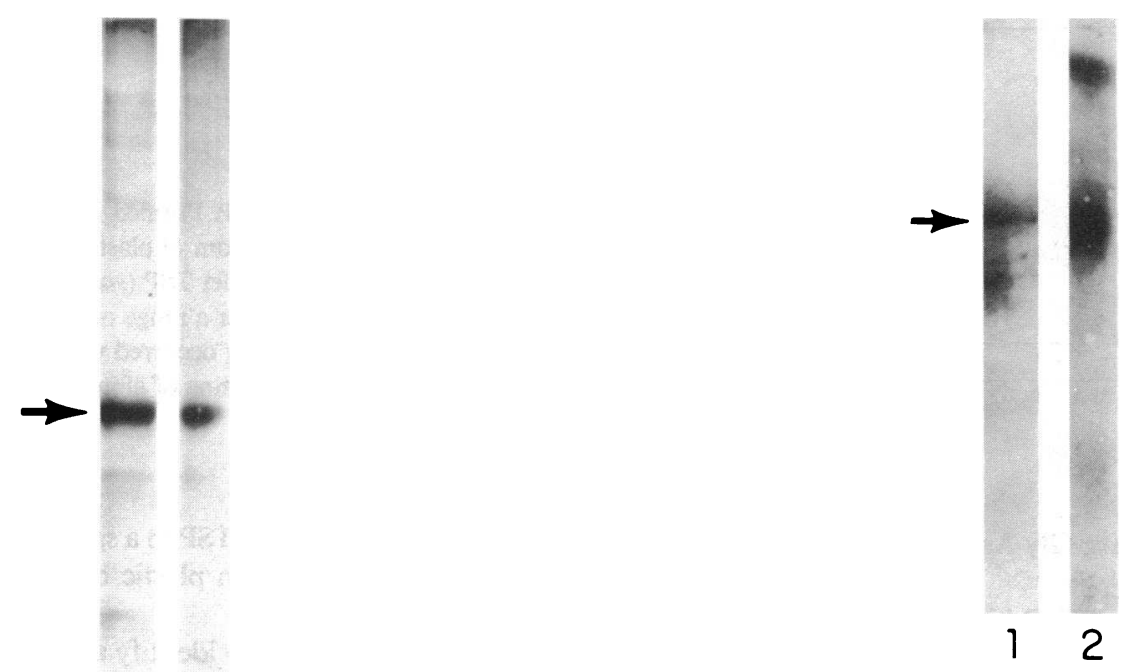

Figure 7. TSP binding to electrophoretic blot of the isolated OKM5 antigen; reactivity with antiGPIV antibody. $\sim 10 \mu \mathrm{g}$ of immunoisolated OKM5 antigen from platelets were run on a 7.5\% SDS-PAGE gel, electrophoretically transferred to nitrocellulose paper, incubated with TSP (50 $\mu \mathrm{g} / \mathrm{ml})$ in PBS with $0.05 \%$ Tween, 2 $\mathrm{mM} \mathrm{CaCl}_{2}, 2 \mathrm{mM} \mathrm{MgCl}$, and $1 \%$ bovine serum albumin, and probed with a gold-labeled second antibody (lane 1). A single 88-kD band is present. Lane 2 is a Western blot of OKM5 antigen with detection by polyclonal rabbit anti-GPIV antibody. A single specific band is present at 88 $\mathrm{kD}$. Another band at $200 \mathrm{kD}$ was present also in blots using normal rabbit IgG as a control and was not further identified.
Figure 5. Immunoisolation of the OKM5 antigen. Purified OKM5 antigen was obtained from C32 melanoma cells and from human platelets using an OKM5 immunoaffinity column. The purified material was subjected to $7.5 \%$ SDSPAGE and silver stained. Lane 1 is platelet derived; lane 2 is derived from C32 melanoma cells. Both cells demonstrate the presence of a

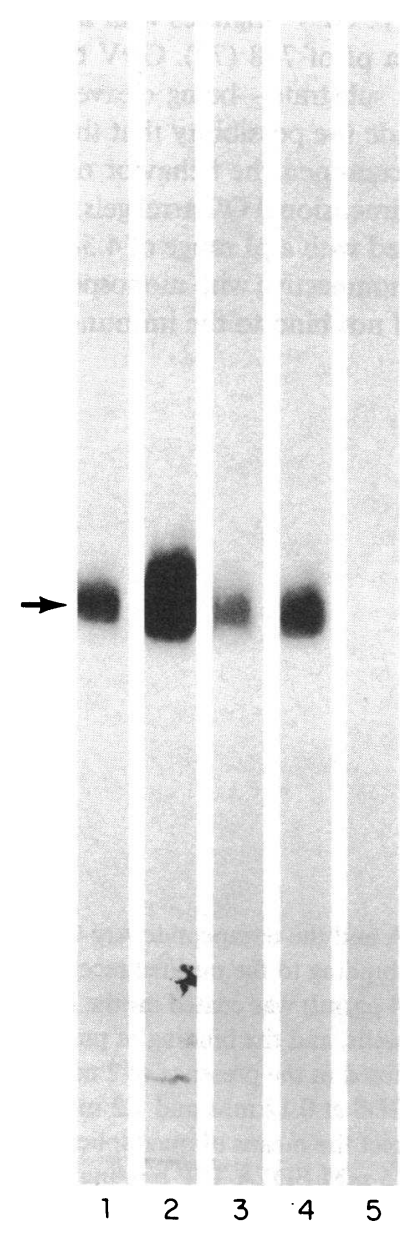

Figure 6. Biosynthetic radiolabeling of OKM5 antigen. C32 melanoma cells were radiolabeled with ${ }^{3} \mathrm{H}$-mannose, -fucose, -galactosamine, or -glucosamine $(0.5 \mathrm{mCi} /$ $\mathrm{ml}$ ) for $24 \mathrm{~h}$ and OKM5 antigen was immunoprecipitated using OKM5 Mab coupled to Affigel 10 beads. Autoradiography reveals the presence of a single molecular weight species of $88 \mathrm{kD}$. tibody confirmed reactivity specifically with the $88-\mathrm{kD}$ material (lane 2). A nonspecific band of apparent $\mathrm{Mr}$ of $200 \mathrm{kD}$ was present in both experimental as well as control blots with normal rabbit antisera. Immunoblots using a specific anti-GPV antisera were negative; as were ligand blots using ${ }^{125} \mathrm{I}$-labeled thrombin (data not shown).

To further examine the specificity of TSP binding to the OKM5 Mab antigen, several studies were performed with the purified material in ELISA binding experiments. TSP or albumin $(4 \mu \mathrm{g} / \mathrm{ml})$ were coated on microtitre wells and binding of the purified OKM5 antigen was quantified with OKM5 Mab followed by alkaline phosphatase conjugated goat anti-mouse IgG (Fig. 8). Binding of OKM5 antigen to immobilized TSP was more than 10-fold greater than that observed with immobilized albumin. These results show specific binding of the OKM5 antigen to TSP and exclude the possibility that the observed binding of TSP was due to a minor contaminant present in the preparation.

To define the characteristics of TSP binding to the purified receptor in an isolated system, microtitre wells with immobilized OKM5 antigen were incubated with TSP or albumin in concentrations up to $400 \mathrm{nM}$. Binding was quantified using alkaline phosphatase conjugated second antibodies followed by colorimetric substrate (Fig. 9). Preincubation of the immobilized antigen with OKM5 Mab in similar experiments reduced TSP binding by one half. The apparent $\mathrm{Kd}$ of the receptor-TSP binding in this system was $\sim 50 \mathrm{nM}$. Albumin binding was not significant. Binding was inhibited in the presence of EDTA but

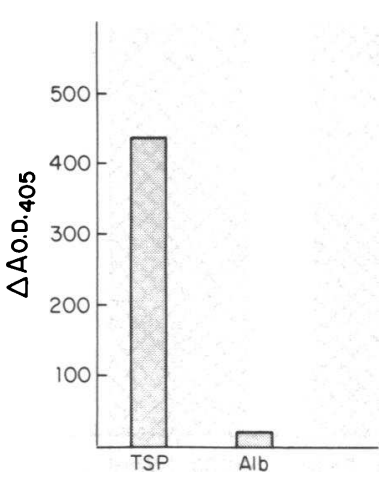

Figure 8. Binding of the isolated receptor to TSP. TSP or albumin $(4 \mu \mathrm{g} / \mathrm{ml})$ were coated on the bottom of plastic microtitre wells, and the binding of the purified OKM5 antigen $(4 \mu \mathrm{g} / \mathrm{ml})$ to the immobilized proteins was examined. Following incubation and washing, the wells were probed with OKM5 Mab followed by alkaline phosphatase-conjugated goat anti-mouse antibody, and O.D.40s measured after the addition of the colorimetric substrate, p-nitrophenyl phosphate. 


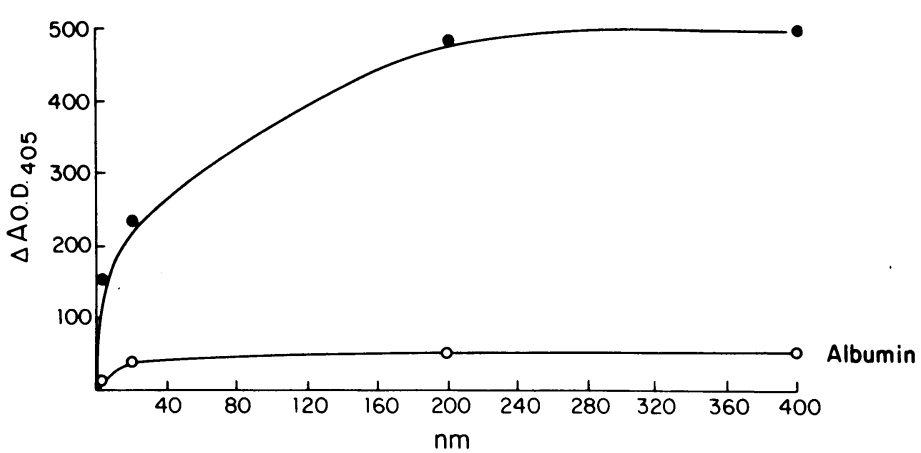

Figure 9. Affinity of the purified receptor for TSP. Purified OKM5 antigen $(4 \mu \mathrm{g} / \mathrm{ml})$ was coated on the bottom of plastic microtiter wells and the binding of purified platelet TSP (solid circles) or albumin (open circles) was studied over a range of concentrations. In this system saturable TSP binding occurred with an apparent $\mathrm{Kd}$ of $\sim 50 \mathrm{nM}$. No significant binding of albumin to the receptor was observed. was not inhibitable by the tetrapeptide Arg-Gly-Asp-Ser (Fig. 10).

To further examine the specificity of binding, TSP binding was examined in the presence of monoclonal anti-TSP antibodies. C6.7 $(500 \mu \mathrm{g} / \mathrm{ml})$, an anti-TSP monoclonal that inhibits the secretion-dependent phase of platelet aggregation (70) partially blocked TSP binding. Two anti-TSP monoclonals, that have no effect of platelet aggregation, 11.4 and $45.2(100 \mu \mathrm{g} /$ $\mathrm{ml}$ ), completely blocked TSP binding to the immobilized receptor (data not shown). Thus, TSP binding to GPIV appears to be mediated by a domain or domains that are recognized by these antibodies.

\section{Discussion}

We have identified and isolated an $88-\mathrm{kD}$ glycoprotein, present on platelets, endothelial cells, monocytes, and a variety of human tumor cell lines, that functions as the membrane TSP binding site. The membrane protein is reactive with OKM5 Mab as well as polyclonal anti-GPIV antibody. In binding studies using whole cells, OKM5 Mab as well as polyclonal anti-GPIV antibody inhibited TSP binding, and in studies on human platelets OKM5 Mab inhibited activation inducible endogenous TSP expression. Biosynthetic labeling with ${ }^{3} \mathrm{H}$-mannose, -fucose, -galactosamine, or -glucosamine demonstrated synthesis of the
88-kD glycoprotein. The isolated protein bound TSP in a specific and saturable manner with an apparent $\mathrm{Kd}$ on plastic coated surfaces of $50 \mathrm{nM}$.

Recently, OKM5 Mab has been reported to identify an antigen on platelets that reacts with antisera to a $90-\mathrm{kD}$ major surface glycoprotein referred to as GPIV (80) or GPIIIb by other nomenclature (79). The material we immunoisolated with OKM5 Mab likewise reacts with anti-GPIV antibody, and TSP binding to cells was inhibited by the polyclonal antibody, thus supporting the conclusion that GPIV functions on the platelet surface and the two cell lines studied, as the membrane TSP binding site. GPIV is increased in platelets from patients with myeloproliferative syndromes, and it is interesting to note that yields of TSP receptor from platelets of such patients were several-fold higher than yields from normal donor platelets (A. Asch, personal observation). Another platelet membrane glycoprotein of similar molecular weight is GPV. GPV migrates with a molecular weight of $82 \mathrm{kD}$ and has a pI of 7-8 (72). GPV binds thrombin and is itself a thrombin substrate-being cleaved by thrombin to $70 \mathrm{kD}(72)$. To exclude the possibility that the receptor we isolated was GPV we examined the behavior of the immunoisolated material in two dimensional O'Farrel gels. The $88 \mathrm{kD}$ material we isolated migrated with a $\mathrm{pI}$ range of 4.5-5.5. In Western blots, the material was nonreactive with monospecific anti-GPV antisera. Thrombin did not bind to the immunoiso-

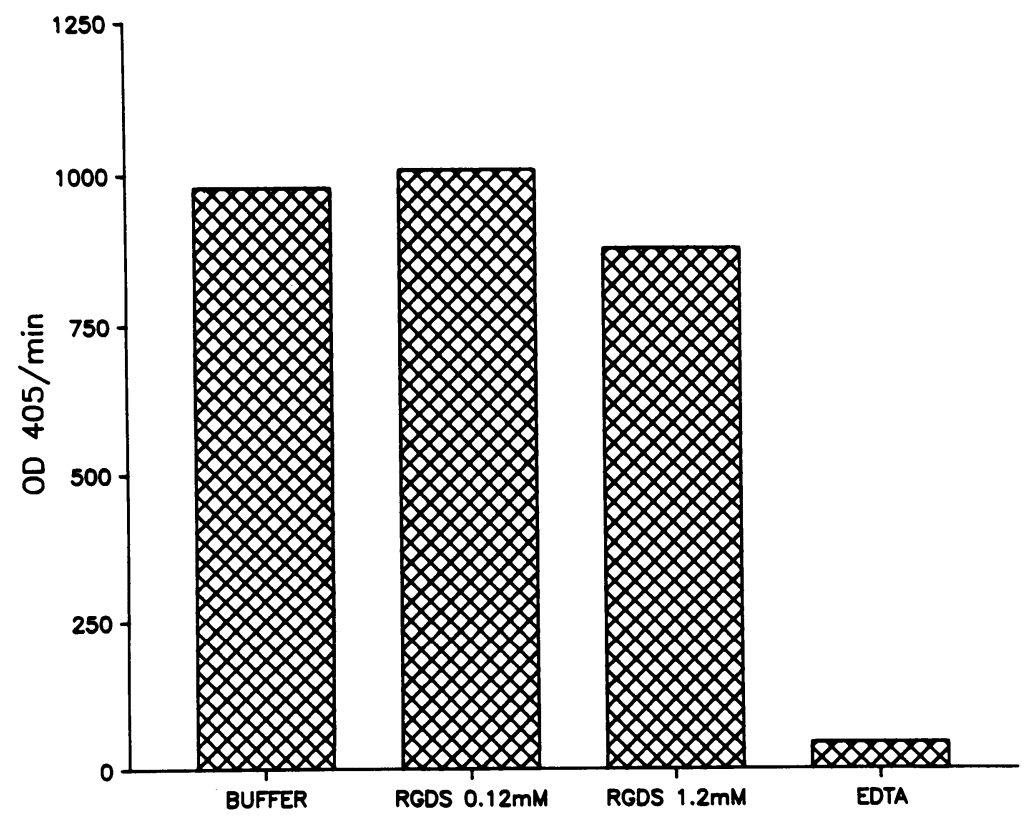

Figure 10. Effect of EDTA and the tetrapeptide Arg-GlyAsp-Ser (RGDS) on TSP binding to the purified receptor. Purified OKM5 antigen $(4 \mu \mathrm{g} / \mathrm{ml})$ was coated on the bottom of plastic microtiter wells, and the binding of purified TSP $(50 \mu \mathrm{g} / \mathrm{ml})$ was examined in the presence of $2 \mathrm{mM}$ $\mathrm{CaCl}_{2}$ with or without RGDS at $0.12 \mathrm{mM}$ and $1.2 \mathrm{mM}$, or $5 \mathrm{mM}$ EDTA. Bars depict the means of quaduplicate points. In the presence of $5 \mathrm{mM}$ EDTA TSP binding was abolished. No effect on binding was observed with RGDS. 
lated receptor in ELISA studies or ligand blots, and the immunoisolated material was not a thrombin substrate. The TSPbinding membrane protein we have isolated is most likely GPIV.

TSP is secreted upon platelet activation and binds to the platelet surface. Our data demonstrate that this binding is mediated by a specific $88-\mathrm{kD}$ membrane receptor previously referred to as GPIV. ${ }^{125} \mathrm{I}$-TSP binding to resting and stimulated platelets has recently been examined and two classes of TSP binding, inducible and noninducible, have been found (81). The possibility exists that conformational changes occurring in a single receptor upon activation may mediate both types of TSP binding. TSP binding to thrombasthenic platelets is normal under resting as well as stimulated conditions $(44,45)$ consistent with the existence of a TSP membrane receptor other than GPIIb/IIIa. In our studies, inducible TSP expression on the platelet surface was completely abrogated by the OKM5 Mab. The effect was not due to inhibition of thrombin activation, because the same results were obtained with ionophore stimulation and platelet aggregometry revealed complete aggregation under the conditions we used.

The demonstration of specific and saturable TSP binding to C32 melanoma cells and to the fibrosarcoma cell line HT1080 raises the possibility that TSP localization on the cell surface may be an important component in the malignant phenotype of these cells. The mechanism by which malignant cells give rise to a gross metastasis has been described as a multistep process requiring detachment of a viable cell from the primary tumor mass into the circulation, survival within the circulation, adhesion to and migration through the endothelium and subendothelium of the target tissue, and successful growth in the new environment (82). The factors that mediate these steps are not well known but several intriguing possibilities exist. Some data have been provided that implicate platelet-tumor cell interactions in the process of tumor cell metastasis, and in some murine models, antiplatelet agents inhibit the development of metastatic lesions (83). The platelet-TSP-tumor cell aggregate may serve as a vehicle for efficient transport through the circulation. Alternatively, endogenous TSP production by tumor cell lines such as HT1080 (A. Asch, personal observation) may lead to binding of the adhesive macromolecule to GPIV on the platelet surface and serve as a site for further platelet-tumor cell interaction and substrate adhesion. We have previously demonstrated that TSP can bind plasminogen and modulate plasmin generation at a surface by tissue plasminogen activator (62). Thus, TSP may support egress of malignant cells through basement membrane by localizing plasmin generation at the cell surface, or promote tumor cell adhesion by virtue of its lectinlike activity. TSP synthesis in smooth muscle cells and glial cells is regulated by platelet-derived growth factor (84). Likewise, the TSP receptor, GPIV, may also be modulated by the cell cycle or growth factors.

The discovery of a shared cellular attachment sequence in fibrinogen, fibronectin, vitronectin, von Willebrand factor (28$36,44,45,85)$, and the implied existence of a family of receptors (3) for these molecules suggests that they have broad biological importance. TSP also has a broad tissue distribution but differs from the other adhesion proteins in that it does not bind to GP IIB/IIIa (57) or like molecules (86). Binding of TSP to the platelet surface has recently been shown to be independent of GPIIb/IIIa (44). We have identified the membrane-binding site for TSP that may function as a cell receptor for this large ubiquitous cellular and matrix glycoprotein. Whether this membranebinding site leads to cellular activation via a second messenger or functions solely as an adhesive protein receptor remains to be determined. Whereas the binding of TSP to this membrane protein is calcium dependent, it does not appear mediated by an RGD sequence that has been identified in the cloned TSP message (87). This raises the possibility that GPIV may belong to a class of adhesive membrane receptors that support cell adhesion in an RGD-independent manner. The distribution of the receptor in platelets, endothelial cells, monocytes, and tumor cells parallels TSP's broad distribution and provides a mechanism by which TSP may function as a modulator of membrane function.

\section{Acknowledgments}

We thank Dr. Gideon Goldstein for the generous gift of OKM5 Mab, Dr. G. Jamieson and Dr. N. Tandon for the generous gift of rabbit antiGPIV IgG, Dr. Clemetson for the generous gift of anti-GPV antisera, Dr. V. Dixit for the generous gift of C6.7 Mab, and Dr. V. Nussensweig for the generous gift of A $10 \mathrm{Mab}$ and for helpful discussions.

This research was supported by grants HL-18828 from the Specialized Center of Research in Thrombosis and HL-01567-01 from the National Institutes of Health.

\section{References}

1. Boucaut, J. C., T. Darribere, T. J. Poole, H. Aoyama, K. M. Yamanda, and J. P. Thiery. 1984. Biologically active synthetic peptides as probes of embryonic development: a competitive peptide inhibitor of fibronectin function inhibits gastrulation in amphibian embryos and neural crest cell migration in avian embryos. J. Cell Biol. 99:1822-1830.

2. Edelman, G. M. 1985. Cell adhesion and the molecular processes of morphogenesis. Am. Rev. Biochem. 54:135-169.

3. Ruoslahti, E., E. G. Hayman, and M. D. Pierschbacher. 1985. Extracellular matrices and cell adhesion. Arteriosclerosis. 5:581-594.

4. Ali, U., and R. O. Hynes. 1978. Effects of LETS glycoprotein on cell motility. Cell. 14:439-446.

5. McCarthy, J. B., S. L. Palm, and L. T. Furcht. 1983. Migration by heptotaxis of a Schwann cell tumor line to the basement membrane glycoprotein laminin. J. Cell Biol. 97:772-777.

6. McCarthy, J. B., and L. T. Furcht. 1984. Laminin and fibronectin promote the haptotaxis of B16 melanoma cells in vitro. J. Cell Biol. 98: 1474-1480.

7. Situ, R., E. C. Lee, J. P. McCoy, and J. Varani. 1984. Stimulation of murine tumor cell motility by laminin. J. Cell Sci. 70:167-176.

8. Lacovara, J., E. B. Carter, and J. P. Quigley. 1984. Fibronectin enhancement of directed migration of B16 melanoma cells. Cancer Res. 44:1657-1663.

9. Malinoff, H. L., J. P. McCoy, J. Varani, and M. S. Wicha. 1984. Metastatic potential of murine fibrosarcoma cells is influenced by cell surface laminin. Int. J. Cancer. 33:651-655.

10. Ruoslahti, E. 1984. Fibronectin in cell adhesion and invasion. Cancer Metastasis Reviews. 3:43-51.

11. McCarthy, J. B., S. T. Hagen, and C. T. Furcht. 1986. Human fibronectin contains distinct adhesion and motility promoting domains on metastatic melanoma cells. J. Cell Biol. 102:179-188.

12. Terranova, V. P., J. E. Williams, L. A. Liotta, and G. R. Martin. 1985. Modulation of the metastatic activity of melanoma cells by laminin and fibronectin. Science (Wash. DC). 226:982-985.

13. Basara, M. L., J. B. McCarthy, D. W. Barnes, and L. T. Furcht. 1985. The stimulation of heptotaxis and migration of tumor cells by serum spreading factor. Cancer Res. 45:2487-2494.

14. Lesot, L., U. Kuhi, and K. von der Mark. 1983. Isolation of laminin-binding protein from muscle cell membranes. EMBO (Eur. Mol. Biol. Organ.) J. 2:861-865.

15. Malinoff, H. L., and M. S. Wicha. 1983. Isolation of cell surface receptor protein for laminin from murine fibrosarcoma cells. J. Cell Biol. 96:1475-1479. 
16. Mollenhauer, J., J. A. Bee, M. A. Lizarbe, and K. von der Mark. 1983. Role of anchorin C11, a 31,000-mol-wt membrane protein, in the interaction of chondrocytes with type II collagen. J. Cell Biol. 98:15721578.

17. Liotta, L. A., P. H. Hand, C. N. Rao, G. Bryant, S. H. Barsky, and J. Scholm. 1985. Monoclonal antibodies to the human laminin receptor recognize structurally distinct sites. Exp. Cell Res. 156:117-126.

18. Pytela, R., M. D. Pierschbacher, and E. Ruoslahti. 1985. A125/ $115 \mathrm{kDa}$ cell surface receptor specific for virtonectin interacts with the Arg-Gly-Asp adhesion sequence derived from fibronectin. Proc. Natl. Acad. Sci. USA. 82:5766-5770.

19. Pytela, R., M. D. Pierschbacher, and E. Ruoslahti. 1985. Identification and isolation of a $140 \mathrm{kd}$ cell surface glycoprotein with properties expected of a fibronectin receptor. Cell. 40:191-198.

20. Marguerie, G. A., E. F. Plow, T. S. Edgington. 1979. Human platelets possess an inducible and saturable receptor specific for fibrinogen. J. Biol. Chem. 254:5357-5363.

21. Bennett, J. S., and G. Vilaire. 1979. Exposure of platelet fibrinogen receptors by ADP and epinephrine. J. Clin. Invest. 64:1393-1398.

22. Bennett, J. S., J. A. Hoxie, S. F. Leitman, G. Vilaire, and D. B. Cines. 1983. Inhibition of fibrinogen binding to stimulated human platelets by a monoclonal antibody. Proc. Natl. Acad. Sci. USA. 80:24172421.

23. Coller, B. S., E. I. Peerschke, L. E. Scudder, and C. A. Sullivan. 1983. A murine monoclonal antibody that completely blocks the binding of fibrinogen to platelets produces a thrombasthenic-like state in normal platelets and binds to glycoprotein IIb and/or IIIa. J. Clin. Invest. 72: 325-338.

24. Ruggeri, Z. M., L. De Marco, L. Gatti, R. Bader, and R. R. Montgomery. 1983. Platelets have more than one binding site for von Willebrand Factor. J. Clin. Invest. 72:1-12.

25. George, J. N., A. T. Nurden, and D. R. Phillips. 1984. Platelet aggregation. N. Engl. J. Med. 311:1084-1098.

26. Mosher, D. F., D. M. Pesciotta, J. C. Loftus, and R. M. Albrecht. 1985. Secreted alpha granule proteins. The race for receptors. In Platelet Membrane Glycoproteins. J. N. George, D. R. Phillips, and A. T. Murden, editors. Plenum Press, New York. In press.

27. Nachman, R. L., and L. L. Leung. 1982. Complex formation of platelet membrane glycoproteins IIb and IIIa with fibrinogen. J. Clin. Invest. 69:263-269.

28. Plow, E. F., M. D. Pierschbacher, E. Ruoslahti, G. A. Marguerie, and M. H. Ginsberg. 1985. The effect of Arg-Gly-Asp containing peptides on fibrinogen and von Willebrand Factor binding to platelets. Proc. Natl. Acad. Sci. USA. In press.

29. Ginsberg, M., M. D. Pierschbacher, E. Ruoslahti, G. Marguerie, and E. Plow. 1985. Inhibition of fibronectin binding to platelets by proteolytic fragments and synthetic peptides which support fibroblast adhesion. J. Biol. Chem. 260:3931-3936.

30. Ginsberg, M. H., J. Forsyth, A. Lightsey, J. Chediak, and E. Plow. 1983. Reduced surface expression and binding of fibronectin to thrombin-stimulated thromboasthenic platelets. J. Clin. Invest. 71:619624.

31. Pierschbacher, M. D., E. Ruoslahti, J. Sundelin, P. Lind, and P. A. Peterson. 1982. The cell attachment domain of fibronectin. Determination of its primary structure. J. Biol. Chem. 257:9593-9597.

32. Pierschbacher, M. D., E. G. Hayman, and E. Ruoslahti. 1983. Synthetic peptide with cell attachment activity of fibronectin. Proc. Natl. Acad. Sci. USA. 80:1224-1227.

33. Pierschbacher, M. D., and E. Ruoslahti. 1984. Cell attachment activity of fibronectin can be duplicated by small synthetic fragments of the molecule. Nature (Lond.). 309:30-33.

34. Pierschbacher, M. D., and E. Ruoslahti. 1984. Variants of the cell recognition site of fibronectin that retain attachment-promoting activity. Proc. Natl. Acad. Sci. USA. 81:5985-5988.

35. Yamada, K. M., and D. W. Kennedy. 1984. Dualistic nature of adhesive protein function: fibronectin and its biologically active peptide fragments can autoinhibit fibronectin function. J. Cell Biol. 99:29-36.

36. Doolittle, R. F., K. W. K. Watt, B. A. Cottrell, D. D. Strong, and M. Riley. 1979. The amino acid sequence of the $\alpha$-chain of human fibrinogen. Nature (Lond.). 280:464-468.

37. Fitzgerald, E. A., I. F. Charo, and D. R. Phillips. 1985. Human and bovine endothelial cells synthesize membrane proteins similar to human platelet glycoprotein IIb and IIIa. J. Biol. Chem. 260:1089310896.

38. Charo, I. F., L. A. Fitzgerald, and D. N. Phillips. 1985. Human smooth muscle cells and a fibroblast-like cell line (MG 63) express surface glycoproteins that are similar to platelet GPIIb and GPIIIa. Blood. 66(Suppl. 1):1094a.

39. Baenziger, N. L., N. Brodie, and P. W. Majerus. 1971. A thrombinsensitive protein of human platelet membranes. Proc. Natl. Acad. Sci. USA. 68:240-243.

40. Hagen, I. 1975. Effects of thrombin on washed human platelets: changes in subcellular fraction. Biochim. Biophys. Acta. 392:242-254.

41. Lawler, J. W., H. S. Slayter, and J. E. Coligan. 1978. Isolation and characterization of a high molecular weight glycoprotein from human blood platelets. J. Biol. Chem. 273:8609-8616.

42. Gerrard, J. M., D. R. Phillips, G. H. Rao, E. F. Plow, D. A. Walz, R. Ross, L. A. Harker, and J. G. White. 1980. Biochemical studies of two patients with the Gray Platelet syndrome: selective deficiency of platelet alpha granules. J. Clin. Invest. 66:102-109.

43. Nurden, A. T., T. J. Kunicki, D. Dupuis, C. Soria, and J. P. Caen. 1982. Specific protein and glycoprotein deficiencies in platelets isolated form two patients with the Gray Platelet syndrome. Blood. 59: 709-718.

44. Plow, E. F., R. Wolff, and M. H. Ginsberg. 1985. Thrombospondin (TSP) interactions. Thromb. Haemostas. 54:374a.

45. Aiken, M. L., M. H. Ginsberg, and E. F. Plow. 1986. Identification of a new class of inducible receptors on platelets. J. Clin. Invest. 78: 1713-1716.

46. Margossian, S., J. Lawler, and H. Slayter. 1981. Physical characterization of platelet thrombospondin. J. Biol. Chem. 256:7495-7500.

47. Coligan, J. E., and H. S. Slayter. 1984. Structure of thrombospondin. J. Biol. Chem. 259:3944-3948.

48. Lawler, J., L. H. Derick, J. E. Connolly, J.-H. Chen, and F. C. Chao. 1985. The structure of human platelet thrombospondin. J. Biol. Chem. 260:3762-3772.

49. Mosher, D. F., M. J. Doyle, and E. A. Jaffe. 1982. Synthesis and secretion of thrombospondin by cultured human endothelial cells. $J$. Cell Biol. 93:343-348.

50. McPherson, J., H. Sage, and P. Bornstein. 1981. Isolation and characterization of a glycoprotein secreted by aortic endothelial cells in culture: apparent identity with platelet thrombospondin. J. Biol. Chem. 256:11330-11336.

51. Jaffe, E. A., J. T. Ruggiero, L. L. K. Leung, M. J. Doyle, P. J. McKeown-Longo, and D. F. Mosher. 1983. Cultured human fibroblasts synthesize and secrete thrombospondin and incorporate it into extracellular matrix. Proc. Natl. Acad. Sci. USA. 80:998-1002.

52. Raugi, G. J., S. M. Mumby, D. Abbott-Brown, and P. Bornstein. 1982. Thrombospondin: synthesis and secretion by cells in culture. $J$. Cell Biol. 95:351-354.

53. Sage, H., F. Farin, G. Striker, and A. Fisher. 1983. Granular pneumocytes in primary culture secrete several major components of the extracellular matrix. Biochemistry. 22:2148-2155.

54. Jaffe, E. A., J. T. Ruggiero, and D. J. Falcone. 1985. Monocytes and macrophages synthesize and secrete thrombospondin. Blood. 65: 79-84.

55. Asch, A. S., L. L. K. Leung, J. Shapiro, and R. L. Nachman. 1986. Human brain glial cells synthesize thrombospondin. Proc. Natl. Acad. Sci. USA. 83:2904-2908.

56. Wight, T. N., G. J. Raugi, S. M. Mumby, and P. Bornstein. 1983. Light microscopic immunolocation of thrombospondin in human tissues. J. Histochem. Cytochem. 33:291-302.

57. Leung, L. L. K., and R. L. Nachman. 1982. Complex formation of platelet thrombospondin with fibrinogen. J. Clin. Invest. 70:542-549.

58. Lahav, J., M. A. Schwartz, and R. O. Hynes. 1982. Analysis of platelet adhesion with a radioactive chemical crosslinking reagent: in- 
teraction of thrombospondin with fibronectin and collagen. Cell. 31: 253-262.

59. Lahav, J., J. Lawler, and M. Gimbrone. 1983. Analysis of the interaction of thrombospondin with fibronectin fibrinogen and thrombospondin. Thromb. Haemostasis. 50:85. (Abstr.)

60. Leung, L. L. K., R. L. Nachman, and P. C. Harpel. 1984. Complex formation of platelet thrombospondin with histidine rich glycoprotein. J. Clin. Invest. 73:5-12.

61. Mumby, S. M., G. J. Raugi, and P. Bornstein. 1984. Interactions of thrombospondin with extracellular matrix proteins: selective binding to type V collagen. J. Cell Biol. 98:646-652.

62. Silverstein, R. L., L. L. K. Leung, P. C. Harpel, and R. L. Nachman. 1984. Complex formation of platelet thrombospondin with plasminogen: modulation of activation by tissue activator. J. Clin. Invest. 74:1625-1633.

63. Jaffe, E. A., L. L. K. Leung, R. L. Nachman, R. Levin, and D. F. Mosher. 1982. Thrombospondin is the endogenous lectin of human platelets. Nature (Lond.). 295:246-248.

64. Leung, L. L. K. 1984. Role of thrombospondin in platelet aggregation. J. Clin. Invest. 74:1764-1772.

65. Roberts, D. H., J. A. Sherwood, S. L. Spitalnick, L. J. Panton, R. J. Howard, V. M. Dixit, W. A. Frazier, L. H. Miller, and V. Ginsburg. 1985. Thrombospondin binds falciparum malaria parasitized erythrocytes and may mediate cytoadherence. Nature (Lond.). 318:64-66.

66. Talle, M. A., P. E. Rao, E. Westberg, N. Allegan, M. Makowski, R. S. Mittler, and G. Goldstein. 1983. Patterns of antigenic expression on human monocytes as defined by monoclonal antibodies. Cell. Immunol. 78:83-87.

67. Knowles, D. M., II, B. Tolidjian, C. Barboe, V. Dagati, M. Grimes, and L. Chess. 1984. Monoclonal anti-human monocyte antibodies OKM1 and OKM5 possess distinctive tissue distribution. J. Immunol. 132:2170-2174.

68. Barnwell, V. M., C. F. Ockenloose, and D. M. Knowles, II. 1985. Monoclonal antibody OKM5 inhibits the in vitro binding of plasmodium falciparum infected erythrocytes to monocytes, endothelial and C32 melanoma cells. J. Immunol. 135:3494-3497.

69. Kinoshita, T., E. Medof, R. Silber, and V. Nussensweig, 1985. Distribution of decay-accelerating factor in the peripheral blood of normal individuals and patients with paroxyșmal nocturnal hemoglobinuria. $J$. Exp. Med. 162:75-92.

70. Dixit, V. M., D. M. Haverstick, K. M. O’Rourke, S. W. Hennessey, G. A. Grant, S. A. Santoro, and W. A. Frazier. 1985. A monoclonal antibody against human thrombospondin inhibits platelet aggregation. Proc. Natl. Acad. Sci. USA. 82:3472-3476.

71. Silverstein, R. L., and R. L. Nachman. 1986. Thrombospondin binds to monocytes-macrophages and mediates platelet-monocyte adhesion. J. Clin. Invest. In press.

72. Bienz, D., W. Schnippering, and K. J. Clemetson. 1986. Glycoprotein $\mathrm{V}$ is not the thrombin activation receptor on human blood platelets. Blood. 68:720-725.
73. McPherson, J. 1983. A practical computer based approach to the analysis of radioligand binding experiments. Comput. Programs Biomed. 17:107-114.

74. Munson, P. D., and D. Robard. 1980. Ligand: a versatile computerized approach for characterization of ligand binding systems. Anal. Biochem. 107:220-239.

75. Laemmli, V. K. 1980. Cleavage of structure proteins during the assembly of the head of bacteriophage $T_{4}$. Nature (Lond.). 227:680-685.

76. Voller, A., D. Bidwell, and A. Bartlett. 1976. Microplate enzyme immunoassays for the immunodiagnosis of virus infections. In Manual of Clinical Immunology. N. R. Rose and H. Friedman, editors. American Association of Microbiology, Washington, DC 506-512.

77. Phillips, D., L. Jennings, and H. R. Prasanna. 1980. Ca ${ }^{2+}$-mediated association of glycoprotein $\mathrm{G}$ (thrombin-sensitive protein, thrombospondin) with human platelets. J. Biol. Chem. 255:11629-11630.

78. Schmidt, J. A., I. J. Vdeinya, J. H. Leeca, R. J. Hay, M. Aikawa, J. W. Barnwell, I. Green, and L. H. Miller. 1982. An amelanotic melanoma cell line bears receptors for the knob ligand on infected erythrocytes. J. Clin. Invest. 70:379-386.

79. Clemetson, K. J. 1985. Glycoproteins of the platelet plasma membrane. In Platelet Membrane Glycoproteins. J. N. George, A. T. Nurden, and D. R. Phillips, editors. Plenum Press, New York.

80. Tandon, N. N., A. Hines, and G. A. Jamieson. 1985. Role for glycoprotein IV in collagen induced platelet aggregation. Blood. 66(Suppl. 1):1148a.

81. Wolff, R., E. F. Plow, and M. H. Ginsberg. 1986. Interaction of thrombospondin with resting and stimulated human platelets. J. Biol. Chem. 261:6840-6846.

82. Poste, G., J. Doll, I. R. Hart, and I. J. Fidler. 1980. In vitro selection of murine B16 melanoma variants with enhanced tissue invasive properties. Cancer Res. 40:1636-1644.

83. Karpatkin, S., and E. Pearlstein. 1981. Role of platelets in tumor cell metastasis. Ann. Intern. Med. 95:636-641.

84. Majack, R. A., S. C. Cook, and P. Bornstein. 1985. Platelet derived growth factor and heparin-like glycosaminoglycans regulate thrombospondin synthesis and deposition in the matrix by smooth muscle cells. J. Cell Biol. 101:1059-1070.

85. Plow, E. F., R. P. McEver, B. S. Coller, V. L. Woods, G. A. Margueries, and M. H. Ginsberg. 1985. Related binding mechanism for fibrinogen, fibronectin, von Willebrand factor and thrombospondin in thrombin stimulated human platelets. Blood. 66:724-727.

86. Pytela, R., M. D. Peirschbacher, M. H. Ginsberg, E. F. Plow, and E. Ruoslahti. 1986. Platelet membrane glycoprotein IIb/IIIa: member of Arg-Gly-Asp-specific adhesion receptors. Science (Wash. DC). 231: 1559-1562.

87. Lawler, J., and R. O. Hynes. 1986. The structure of human thrombospondin, an adhesive glycoprotein with multiple calcium-binding sites and homologies with several different proteins. J. Cell Biol. 103: 1635-1648. 